\title{
Assessment of Lithium, Macro- and Microelements in Water, Soil and Plant Samples from Karst Areas in Romania
}

\author{
Anamaria Iulia Török ${ }^{1}$, Ana Moldovan ${ }^{1,2, *}$, Erika Andrea Levei ${ }^{1} \mathbb{D}$, Oana Cadar ${ }^{1}$ (D) , Claudiu Tănăselia ${ }^{1}$ \\ and Oana Teodora Moldovan ${ }^{3}$ (D)
}

Citation: Török, A.I.; Moldovan, A.; Levei, E.A.; Cadar, O.; Tănăselia, C.; Moldovan, O.T. Assessment of Lithium, Macro- and Microelements in Water, Soil and Plant Samples from Karst Areas in Romania. Materials 2021, 14, 4002. https://doi.org/ $10.3390 /$ ma14144002

Academic Editor: Mihkel Koel

Received: 10 June 2021

Accepted: 14 July 2021

Published: 17 July 2021

Publisher's Note: MDPI stays neutral with regard to jurisdictional claims in published maps and institutional affiliations.

Copyright: (c) 2021 by the authors. Licensee MDPI, Basel, Switzerland. This article is an open access article distributed under the terms and conditions of the Creative Commons Attribution (CC BY) license (https:/ / creativecommons.org/licenses/by/ $4.0 /)$.
1 INCDO-INOE 2000, Research Institute for Analytical Instrumentation, 67 Donath, 400293 Cluj-Napoca, Romania; iulia.torok@icia.ro (A.I.T.); erika.levei@icia.ro (E.A.L.); oana.cadar@icia.ro (O.C.); claudiu.tanaselia@icia.ro (C.T.)

2 Faculty of Materials and Environmental Engineering, Technical University, 103-105 Muncii Boulevard, 400641 Cluj-Napoca, Romania

3 Cluj Department, Emil Racovita Institute of Speleology, 5 Clinicilor, 400006 Cluj-Napoca, Romania; oanamol35@gmail.com

* Correspondence: ana.moldovan@icia.ro

\begin{abstract}
Lithium is a critical element for the modern society due to its uses in various industrial sectors. Despite its unequal distribution in the environment, Li occurrence in Romania was scarcely studied. In this study a versatile measurement method using ICP-MS technique was optimized for the determination of Li from various matrixes. Water, soil, and plant samples were collected from two important karst areas in the Dobrogea and Banat regions, Romania. The Li content was analyzed together with other macro- and microelement contents to find the relationship between the concentration of elements and their effect on the plants' Li uptake. In Dobrogea region, half of the studied waters had high Li concentration, ranging between 3.00 and $12.2 \mu \mathrm{g} / \mathrm{L}$ in the case of water and between 0.88 and $11.1 \mathrm{mg} / \mathrm{kg} \mathrm{DW}$ in the case of plants, while the Li content in the soil samples were slightly comparable (from 9.85 to $11.3 \mathrm{mg} / \mathrm{kg} \mathrm{DW}$ ). In the Banat region, the concentration of Li was lower than in Dobrogea (1.40-1.46 $\mu \mathrm{g} / \mathrm{L}$ in water, 6.50-9.12 mg/kg DW in soil, and $0.19-0.45 \mathrm{mg} / \mathrm{kg}$ DW in plants). Despite the high Li contents in soil, the Li was mostly unavailable for plants uptake and bioaccumulation.
\end{abstract}

Keywords: lithium; groundwater; karst; plants; Lolium; Urtica; Mentha; bioconcentration factor

\section{Introduction}

Lithium (Li) is one of the most "critical" metals for modern society used in many fields such as manufacturing electronic devices, glass and ceramics, as well in medical and cosmetics products [1]. It is the 30th most abundant element in the upper continent crust with similar abundance to $\mathrm{Pb}$ and $\mathrm{Cu}$, naturally occurring in waters, soils, rocks, and minerals (such as lithium micas, amblygonite, petalite, lepidolite, spodumene, eucryptite) [2-4]. The average concentrations in shale and granitic rocks are 5 to 10 times higher than those in carbonate-based rocks [3]. The main source of Li in the environment is the weathering of minerals, its abundance depending on the lithology, topography, and hydrology.

The biochemical role of $\mathrm{Li}$ in the lifecycle of living organisms is unclear, though is considered to have a potential role as a micronutrient [5]. It is adsorbed by sodium channels in the intestines and it can be detected in the serum, saliva, and urine [2]. Microdoses of Li intake through drinking water may have antisuicidal, mood-stabilizing, antidepressive and antimanic effects. Moreover, the dietary Li was found to have a beneficial role in the prevention of dementia and Alzheimer's diseases [2,6,7]. However, the biochemical mechanisms are still unelucidated. Some studies report that the positive association of $\mathrm{Li}$ consumption is overestimated or there is a lack of data on the long-term effects of Li intake [6]. Overall, more investigation needs to be conducted to verify the hypothesis that 
Li has a potentially protective and beneficial impact on human health and to determine the role of the naturally occurring $\mathrm{Li}$ in different regions. In addition, the identification of potential dietary Li sources is relevant for future research areas [6].

Drinking water, grains, or vegetables can be a major Li source for humans [5]. A recent study reported that the Li content in food samples ranges between $<0.001$ and $4.238 \mathrm{mg} / \mathrm{kg}$, with vegetables containing the highest concentration followed by milk, cheese, meat, and oil products [8]. Naturally, the Li concentration ranges between 7 and $200 \mathrm{mg} / \mathrm{kg}$ in soil, between 1 and $10 \mu \mathrm{g} / \mathrm{L}$ in surface water, and around $20 \mu \mathrm{g} / \mathrm{L}$ in seawater [9]. European survey studies reported $\mathrm{Li}$ concentrations in bottled and tap water ranging between 2.65 and $14.9 \mu \mathrm{g} / \mathrm{L}$ [9]. Therefore, the estimation of Li daily intake can be different depending on the availability in the environment and food products [10].

Karst aquifers are an important resource of water, providing 50\% of the world's drinking water [11]. The sources of $\mathrm{Li}$ in a karst system are mainly represented by silicate dissolution, atmospheric input via rainfall and sea-spray aerosol, followed by carbonate dissolution [12]. Generally, the drinking water Li concentrations can vary from $<1$ to $219 \mu \mathrm{g} / \mathrm{L}[2,13,14]$. Presently, there are no recommendations or regulatory thresholds for Li concentration in drinking water.

Li concentrations can be determined using different analytical techniques such as atomic absorption spectrometry (AAS), inductively coupled plasma atomic emission spectrometry (ICP-AES), and inductively coupled plasma mass spectrometry (ICP-MS) or by ion-selective electrodes [15]. Of these, the ICP-MS technique is a sensitive method that was frequently used for determination of elements from various types of samples, such as water, wine, saliva, blood, urine, plant, sediment, and rocks [2].

The identification and assessment of Li resources is a key step for understanding lithium metallogeny. Moreover, the identification of the Li uptake rate is another important factor, which can contribute to a better understanding of the role of $\mathrm{Li}$ in the living organisms. In this study, a versatile quantitative ICP-MS method for Li determination in three different sample matrixes (water, soil, and plant samples) was optimized and the relationship between the $\mathrm{Li}$, macroelements $(\mathrm{Na}, \mathrm{Mg}, \mathrm{Al}, \mathrm{K}, \mathrm{Ca}, \mathrm{Fe}, \mathrm{Mn}$ ) and microelements $(\mathrm{Cr}, \mathrm{Co}, \mathrm{Ni}, \mathrm{Cu}, \mathrm{Zn}, \mathrm{Pb}, \mathrm{Sr}, \mathrm{Ba}, \mathrm{V}, \mathrm{As}, \mathrm{Sr}, \mathrm{Cd}, \mathrm{Pb})$ concentration in water, soil, and plants (ryegrass-Lolium sp., nettles-Urtica sp., and mint-Mentha sp.) in two important karst areas from Romania were assessed to display the divergence of the Li content in the samples and to find a connection between Li concentration in plants compared to soil and water.

\section{Materials and Methods}

\subsection{Description of the Study Areas and Sampling Campaign}

Groundwater, soil, and plant samples were collected in September 2020 from six sampling points located in: rural areas of Dobrogea region, south-eastern Romania (GWR27, GWR28, GWR29, and GWR30) and a protected area of Banat region, south-western Romania (GN and GWR6). Details on sampling sites, geology, soil type, and type of plants collected are given in Table 1. Dobrogea is characterized by faulted limestones, dolomitic limestones, and thick layers of carbonate successions, the main groundwater type for the sampling sites being represented by local or discontinuous aquifers in fissured rocks [16]. The parental bedrock materials of the study area from Banat region mainly includes Barremian-Aptian limestones, while the groundwater sources are related to extended aquifers (GN) and local or discontinuous aquifers (GWR6). The predominant soil type in Dobrogea is cambic-chernozem and chernozem, while in southern Banat region is cambisol with rendzinas and rocky areas in the zones with karst $[17,18]$.

In each sampling site, $1 \mathrm{~L}$ of groundwater was collected from springs in precleaned polyethylene bottles and kept at $4{ }^{\circ} \mathrm{C}$ until analysis. A composite soil sample (1.5-2 kg) was obtained by mixing 5 subsamples collected from an area of $50 \mathrm{~m}^{2}$ in the vicinity of each spring, from a depth of 0-30 cm and by using a stainless-steel shovel. Depending on their presence near each spring, 3 to 5 plants were collected with a Teflon coated knife. The soil and plant samples were stored in paper bags during transport to laboratory. 
Table 1. Geology and geographic settings of studied samples.

\begin{tabular}{|c|c|c|c|c|c|c|}
\hline & \multicolumn{2}{|c|}{ Banat } & \multicolumn{4}{|c|}{ Dobrogea } \\
\hline & GN & GWR6 & GWR27 & GWR28 & GWR29 & GWR30 \\
\hline Location & $\begin{array}{l}44^{\circ} 54^{\prime} 3.82^{\prime \prime} \mathrm{N} \\
21^{\circ} 46^{\prime} 29.86^{\prime \prime} \mathrm{E}\end{array}$ & $\begin{array}{l}45^{\circ} 11^{\prime} 16.66^{\prime \prime} \mathrm{N} \\
21^{\circ} 51^{\prime} 16.07^{\prime \prime} \mathrm{E}\end{array}$ & $\begin{array}{l}45^{\circ} 0^{\prime} 53^{\prime \prime} \mathrm{N} \\
28^{\circ} 22^{\prime} 43^{\prime \prime} \mathrm{E}\end{array}$ & $\begin{array}{l}45^{\circ} 0^{\prime} 40^{\prime \prime} \mathrm{N} \\
28^{\circ} 28^{\prime} 10^{\prime \prime} \mathrm{E}\end{array}$ & $\begin{array}{l}44^{\circ} 2^{\prime} 31^{\prime \prime} \mathrm{N} \\
27^{\circ} 57^{\prime} 46^{\prime \prime} \mathrm{E}\end{array}$ & $\begin{array}{l}43^{\circ} 59^{\prime} 21^{\prime \prime} \mathrm{N} \\
28^{\circ} 0^{\prime} 29^{\prime \prime} \mathrm{E}\end{array}$ \\
\hline $\begin{array}{l}\text { Altitude } \\
\text { (m a.s.l.) }\end{array}$ & 180 & 220 & 139 & 88 & 57 & 78 \\
\hline Soil & Rendzinas & Rendzinas & Chernozems & $\begin{array}{l}\text { Chernozems, } \\
\text { alluvial soils }\end{array}$ & Rendzinas & Alluvial soils \\
\hline Geology & Limestone & Limestone & $\begin{array}{l}\text { Sandstone, } \\
\text { limestone }\end{array}$ & $\begin{array}{l}\text { Sandstone, } \\
\text { limestone }\end{array}$ & $\begin{array}{l}\text { Limestone, marl } \\
\text { limestone, clays, } \\
\text { dolomites }\end{array}$ & $\begin{array}{c}\text { Limestone, clays, } \\
\text { diatomites }\end{array}$ \\
\hline $\begin{array}{l}\text { Predominant plant } \\
\text { species }\end{array}$ & $\begin{array}{l}\text { Lolium sp., } \\
\text { Urtica sp. }\end{array}$ & $\begin{array}{l}\text { Lolium sp., } \\
\text { Urtica sp. }\end{array}$ & $\begin{array}{l}\text { Lolium sp., } \\
\text { Mentha sp. }\end{array}$ & $\begin{array}{l}\text { Lolium sp., } \\
\text { Mentha sp. }\end{array}$ & $\begin{array}{l}\text { Mentha sp., } \\
\text { Urtica sp. }\end{array}$ & $\begin{array}{l}\text { Lolium sp., } \\
\text { Urtica sp. }\end{array}$ \\
\hline
\end{tabular}

\subsection{Sample Preparation}

For the macro- and microelements determination, the water samples were filtered through $0.45 \mu \mathrm{m}$ cellulose acetate membrane filters and acidulated with $65 \% \mathrm{HNO}_{3}$ to $\mathrm{pH}<2$. Soil samples were oven dried at $105^{\circ} \mathrm{C}$, ground to pass through a $2 \mathrm{~mm}$ size sieve, and stored in closed polyethylene bags. An amount of $3 \mathrm{~g}$ of soil sample were digested with a $1: 3 \mathrm{v} / \mathrm{v}$ mixture of $37 \% \mathrm{HCl}$ and $65 \% \mathrm{HNO}_{3}$ [19]. The digested soil samples were transferred into $100 \mathrm{~mL}$ volumetric flasks and diluted with ultrapure water (Elga Veolia, High Wycombe, UK). Plant samples were washed with distilled water, oven dried at $65^{\circ} \mathrm{C}$, and ground by an agate mortar and passed through a $200 \mu \mathrm{m}$ mesh sieve to obtain a homogenized powder. An amount of $2 \mathrm{~g}$ of plant material was digested with $5 \mathrm{~mL} 65 \%$ $\mathrm{HNO}_{3}$ and $2 \mathrm{~mL} \mathrm{30 \%} \mathrm{H}_{2} \mathrm{O}_{2}$. The digested samples were diluted with ultrapure water to a final volume of $25 \mathrm{~mL}$ [19]. The measured metal concentrations are expressed as $\mathrm{mg} / \mathrm{kg}$ dry weight (DW).

All reagents were of analytical purity and were used without further purification. Ultrapure deionized water from a water purification system (Elga Veolia, High Wycombe, UK) and ultra-pure $60 \% \mathrm{HNO}_{3}$ (Merck, Darmstadt, Germany) were used for all dilutions and to prepare the calibration standard solutions. All the labware prior to use were cleaned by soaking for $24 \mathrm{~h}$ in $10 \% \mathrm{HNO}_{3}$ and then rinsed with ultra-pure water.

Analysis of $\mathrm{Na}, \mathrm{Mg}, \mathrm{K}, \mathrm{Ca}$, and Fe was performed using 5300 Optima DV (PerkinElmer, Waltham, MA, USA) Inductively Coupled Plasma Optical Emission Spectrometer (ICP-OES) while Li, Al, V, Cr, Mn, Co, Ni, Cu, Zn, As, Sr, Cd, Ba, and Pb with ELAN DRC II (Perkin-Elmer, Waltham, MA, USA) Inductively Coupled Plasma Quadrupole Mass Spectrometer (ICP-MS). Certified multielement ICP Standard 3 with a concentration of $10 \mu \mathrm{g} / \mathrm{mL}$ (Perkin-Elmer, Waltham, MA, USA) was used to prepare calibration standards. Calibration was linear with correlation coefficients $\left(R^{2}\right)$ above 0.9996.

For the Li measurement, the ICP-MS equipped with a Meinhard type nebulizer containing cyclonic spray chamber and was used under the continuous nebulization conditions. Before each run, the spectrometer was optimized for best signal/noise ratio: an indium solution was fed into the instrument and its signal maximized, while the background was kept below 2 counts per second (cps). To avoid any potential interferences, oxides and double charged ions were kept under 3\% by carefully tunning instrument parameters and oxides and double charged ion formation was monitored by measuring $\mathrm{Ce} / \mathrm{CeO}$ and $\mathrm{Ba} / \mathrm{Ba}^{2+}$ ratios from a certified solution at the beginning of each sample batch. For the quality assurance of results, calibration standards, procedural blank, and triplicate sample measurements were used.

To evaluate the performances of the Li determination in water, soil, and plant samples, the limit of detection (LOD), limit of quantification (LOQ), repeatability, and reproducibility were assessed. The LOD and LOQ were calculated as 3 and 10 times of the standard deviation of the Li intensity of a blank solution containing ultrapure water and $5 \% v / v$ $\mathrm{HNO}_{3}$ [20]. The following certified reference material (CRMs) were analyzed to check the accuracy of the Li measurements: 1643f NIST (National Institute of Standards and Technology, Gaithersburg, MD, USA) for water, SQC001 NIST SRM Loam Clay (Sigma-Aldrich 
RTC, USA) for soil and NIM-GWB 10019 Apple-Trace elements (Institute of Geophysical and Geochemical Exploration, Langfang City, China) for plants.

\subsection{Multivariate Statistics}

Principal component analysis (PCA) is a powerful tool to explain a variance of interrelated variables for reducing the dimensionality of the data set [21]. The main characteristics of the PCA is to reduce a large number of variables into a new set of reduced variables based on their mutual dependence and to identify the difference among the three matrix samples metal concentration and to show a correlation among the variables. In the present study, the PCA was performed using OriginLab (2020b) software based on the eigenvalues of the correlation matrix on standardized data and was used to maximize the variation expressed by the principal components. Only PC's with eigenvalues $>1$ were retained. Also, OriginLab (2020b) software was used to present the soil samples date in heat map associated with the agglomerative hierarchical cluster analysis (HCA) using the HeatMapDendogram Apps with Pearson correlation settings.

\subsection{Bioconcentration Factor}

The bioconcentration factor (BCF) was computed to determine the plant samples macro- and microelement accumulation capacity in the different sampling locations. The $\mathrm{BCF}$ was calculated as the ratio between the metal concentration in the individual plant and the metal concentration in the soil sample, according to the suggestion of Gajić et al. [22].

\section{Results}

\subsection{ICP-MS Parameters Optimization}

To optimize the Li determination from three different sample matrixes using ICP-MS method, some basic characteristics were taken into consideration such as, the sample matrix type (water, soil, and plant samples), the analyte concentration level and range, presence of interfering substances (organic substance content, which was eliminated through samples' mineralization), requirements for the procedure detection limits and quantification based on blank samples, determination of the repeatability based on the standard deviation for data series, and criteria for the use of reference material to describe the accuracy of the analytical procedure.

Li had no interelement spectral interferences. The equipment (ICP-MS, Elan DRC II, Perkin-Elmer) parameters and conditions for the Li determination analytical procedure are given in the Table 2.

Table 2. Used ICP-MS parameters for optimization of Li determination.

\begin{tabular}{cc}
\hline Operating Condition & Setting \\
\hline Nebulizer gas flow & $0.92 \mathrm{~L} / \mathrm{min}$ \\
Auxiliar gas flow & 1.2 \\
Plasma gas flow & 15 \\
ICP RF power & 1350 Watts \\
Lens voltage & 7.75 Volts \\
Analog stage voltage & -1850 \\
Pulse stage voltage & 1050 \\
Scan Mode & Peak Hopping \\
Dwell Time per Amu (ms) & 200 \\
Integration Time (ms) & 4000 \\
Detector & Analog \\
Calibration Coefficient $\left(\mathrm{R}^{2}\right)$ & $0.99954-0.99997$ \\
No. of reading per sample & 5 \\
\hline
\end{tabular}

The dynamic reaction cell (DRC) was used in rf-only mode (vented, no gas) and rejection parameter $\mathrm{q}(\mathrm{RPq})$ of the cell was tuned for maximum Li signal intensity by continuously measuring the signal intensity from the same sample, while varying the $\mathrm{RPq}$ 
value. The second rejection parameter ( $\mathrm{RPa}$ ) was set to its default value (zero) and since its effect on the ion passage through the cell was much more significant, optimization or default value were not necessary. The results for RPq optimization process are displayed in Figure 1.

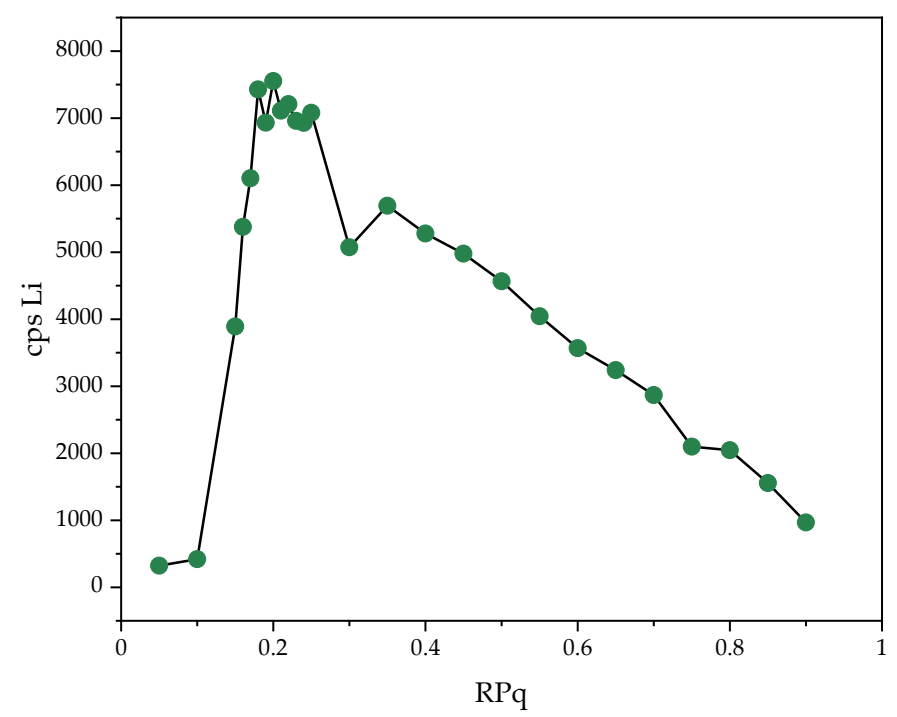

Figure 1. Plot of Li cps in contrast with RPq during method optimization using ICP-MS spectrometer (Perkin-Elmer). A value of $\mathrm{RPq}=0.22$ was used for all Li measurements.

The precision data for the three sample matrixes are given in Table 3. The obtained results indicate acceptable precision in all cases, with an RSD of $4.22 \%$ for the water samples, and $2.46 \%$ and $3.06 \%$ for soil and plant samples, respectively.

Table 3. Precision data (standard deviation-SD, and relative standard deviation-RSD), limit of detection (LOD), and limit of quantification (LOQ) for Li determination in water, soil, and plant sample matrixes using Elan DRC II ICP-MS spectrometer.

\begin{tabular}{cccccc}
\hline Matrix & Concentration & SD & RSD $\%$ & LOD & LOQ \\
\hline Water & $12.2 \mu \mathrm{gg} / \mathrm{L}$ & $0.51 \mu \mathrm{g} / \mathrm{L}$ & 4.22 & $0.12 \mu \mathrm{g} / \mathrm{L}$ & $0.39 \mu \mathrm{g} / \mathrm{L}$ \\
Soil & $9.95 \mathrm{mg} / \mathrm{kg} \mathrm{DW}$ & $0.20 \mathrm{mg} / \mathrm{kg}$ & 2.46 & $0.20 \mathrm{mg} / \mathrm{kg}$ & $0.66 \mathrm{mg} / \mathrm{kg}$ \\
Plant & $8.83 \mathrm{mg} / \mathrm{kg} \mathrm{DW}$ & $0.24 \mathrm{mg} / \mathrm{kg}$ & 3.06 & $0.01 \mathrm{mg} / \mathrm{kg}$ & $0.03 \mathrm{mg} / \mathrm{kg}$ \\
\hline \multicolumn{2}{l}{$n$ p parallel measurements). }
\end{tabular}

The accuracy was estimated by comparing the certified and measured concentrations and by assessing the pooled recovery and confidence interval (CI) for the $95 \%$ confidence level (as illustrated in Table 4). Data for the analysis of Li concentration in CRMs of water, soil, and plant method showed recovery in the range of $92.9-111 \%$ and a pooled recovery of $96.2 \%$.

Table 4. Certified and measured concentration of $\mathrm{Li}$ in certified reference materials (CRMs).

\begin{tabular}{cccc}
\hline CRM & Matrix & Certified Value $\pm \mathbf{U}^{*}$ & Found Value $\pm \mathbf{C I}$ ** \\
\hline 1643f NIST SRM & Water & $16.6 \pm 0.35 \mu \mathrm{g} / \mathrm{L}$ & $16.3 \pm 1.39$ \\
SQC001 NIST SRM & Soil & $103 \pm 6 \mathrm{mg} / \mathrm{kg}$ & $95.7 \pm 5.38$ \\
NIM-GWB 10019 & Plant & $0.115 \pm 0.009 \mathrm{mg} / \mathrm{kg}$ & $0.13 \pm 0.01$ \\
Recovery range (\%) & - & - & $92.9-111$ \\
Pooled recovery (\%) & - & - & 96.2 \\
\hline
\end{tabular}

${ }^{*} \mathrm{U}=$ is the expanded uncertainty for $95 \%$ confidence level ${ }^{* *} \mathrm{CI}=$ is the confidence interval for $95 \%$ confidence level $(n=3)$. 


\subsection{Water Samples}

The Li concentrations in water samples in comparison with the macro- $(\mathrm{Ca}, \mathrm{K}, \mathrm{Na}$, $\mathrm{Mg}$, Sr) and microelements ( $\mathrm{Fe}, \mathrm{Al}, \mathrm{V}, \mathrm{Cr}, \mathrm{Mn}, \mathrm{Co}, \mathrm{Ni}, \mathrm{Cu}, \mathrm{Zn}, \mathrm{As}$, and $\mathrm{Ba}$ ) concentrations from the six sampling sites are shown in Figure 2 and in Supplementary Tables S1 and S2.
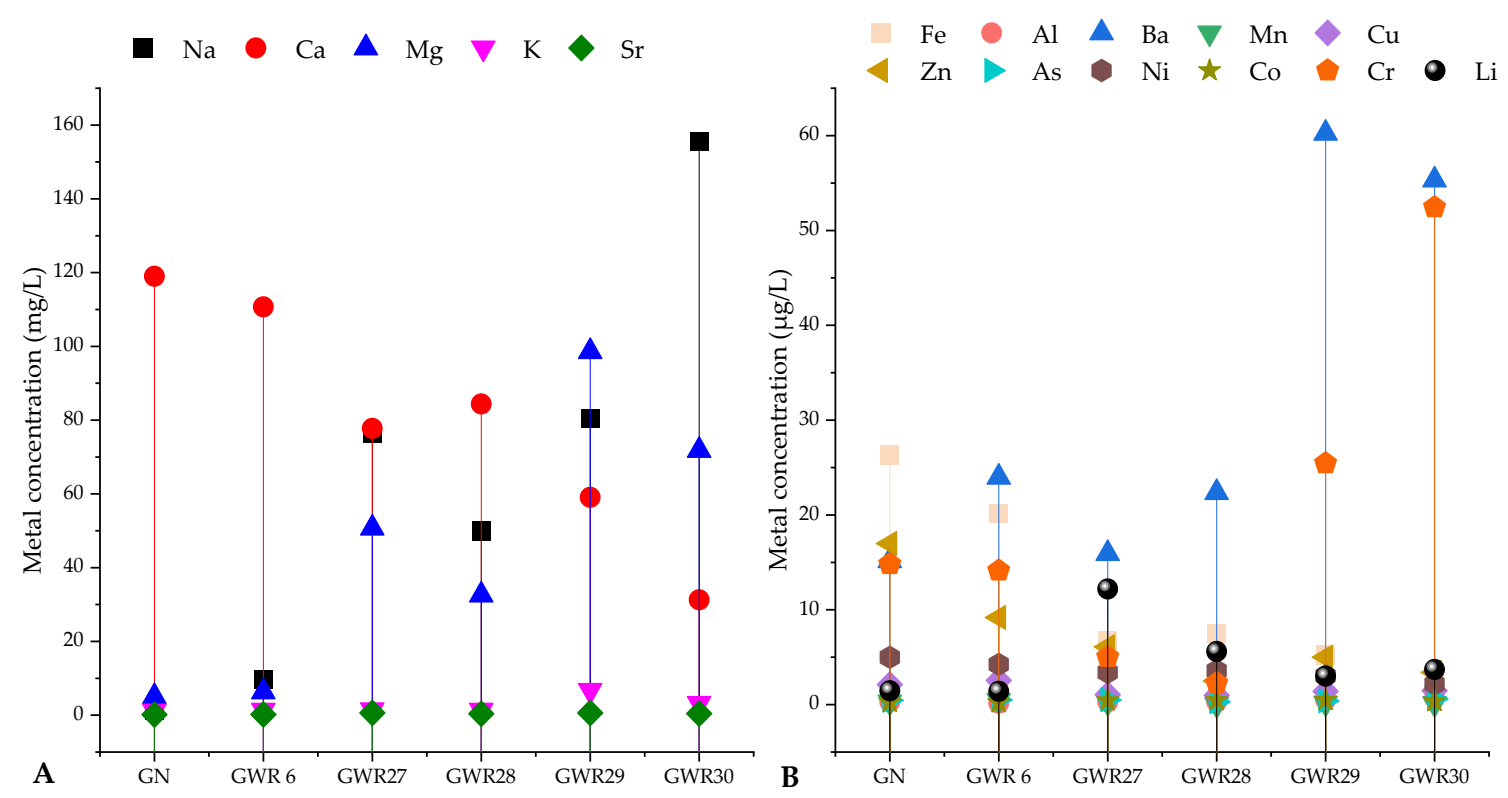

Figure 2. Water samples Li concentration (macro- $(\mathbf{A})$ and microelement contents $(\mathbf{B}))$ in comparison with other elements.

The highest Li concentration was measured in GWR27 followed by GWR28 (12.20 and $5.60 \mu \mathrm{g} / \mathrm{L}$, respectively), while the lowest content was observed in GN and GWR6 (1.46 and $1.40 \mu \mathrm{g} / \mathrm{L}$ ) sampling sites. The Li content in GWR27 was between 2 and 9-times higher than the other sites. More than 100-fold higher Na content was measured in water from GWR30 site than the water from GN site. Meanwhile, in the GN site, the Ca concentration was found to be higher compared to that of the other sites (from GWR27 to GWR30), except for water from GWR6. The highest Mg concentration was measured in waters of GWR29, which was 16 and 20-times greater than the Mg concentration in the water from the GN and GWR6 sites, respectively. The K concentrations in water samples were found to be similar, only in GWR29 exceeded $6 \mathrm{mg} / \mathrm{L}$.

The concentrations of other elements, such as $\mathrm{Al}, \mathrm{Mn}, \mathrm{As}, \mathrm{Co} \mathrm{Cd}, \mathrm{Pb}$, and $\mathrm{V}$, were low or in below the LOQ (lower than $0.70 \mu \mathrm{g} / \mathrm{L}$ ) in all water samples. The highest Ba concentrations were observed in GWR29 and GWR30, almost 4 times higher than in waters from GN, GWR6, and GWR27. However, the highest Fe and Zn concentrations were measured in GN and GWR6. For Cr, the highest concentrations were found in the waters of GWR30 and GWR29. Interestingly, high Sr concentrations were obtained in the water samples from the GWR27 and GWR29 sites.

\subsection{Soil Samples}

The distribution of elements in soil samples are presented in Figure 3 and in Supplementary Tables S1 and S2. Li content had no relevant spatial variation within the two study regions; however, some differences were observed. The soil samples from Dobrogea had a Li content ranging between 9.85 and $11.3 \mathrm{mg} / \mathrm{kg} \mathrm{DW}$, while in Banat, the Li content ranged from 6.50 to $9.95 \mathrm{mg} / \mathrm{kg}$ DW. The highest Li content was measured in the GWR29 site, almost 2-fold greater than the soil sample from GWR6, where the lowest Li content $(6.50 \mathrm{mg} / \mathrm{kg} \mathrm{DW})$ was measured. The GWR29 soil sample have high concentrations of $\mathrm{Ca}, \mathrm{K}$ and Mg. The GWR29 soil had the highest Ca content, followed by GWR30 (200 and $111 \mathrm{~g} / \mathrm{kg}$ of $\mathrm{Ca}$ ), which was about 21-fold greater than in GN and GWR6, indicating a major difference in the chemical processes that controls the soil chemistry in the two studied 
areas. However, compared to that of the other sampling points, the highest $\mathrm{Mg}, \mathrm{K}, \mathrm{Al}, \mathrm{Cu}$, and Zn content were measured in soil of GWR30. The GWR6 soil sample with the lowest $\mathrm{Li}$ content had also the highest $\mathrm{Pb}$ and Ba contents. $\mathrm{Ni}, \mathrm{Cr}$, and Co contents from the GN soil sample were the highest. The Sr content in soil was the highest in case of the GWR27, similar to the water samples. The same tendency was observed for the Fe contents, with the highest values in GN and GRW6.

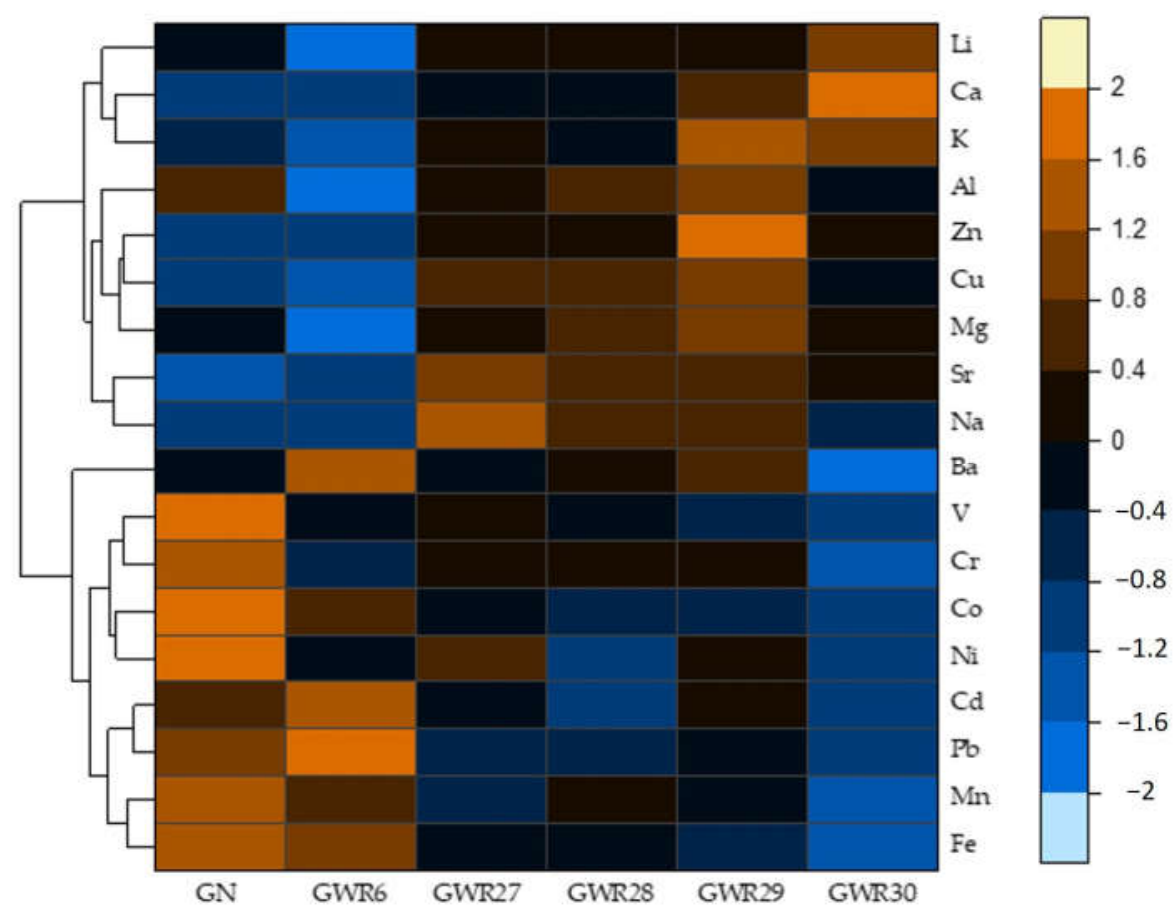

Figure 3. Logarithmic ( $\log 10)$ values of $\mathrm{Li}$ in comparison with other macro- and microelements presented in heatmap with hierarchical clustering dendrogram of elements in soil samples from GN, GWR6, GWR27, GWR28, GWR29, and GWR30 sampling sites.

In the present study, the correlations and similarities among the chemical indicators of the soil samples were established by HCA, as shown in Figure 3. The performed HCA grouped the chemical parameters into three clusters. One cluster included $\mathrm{Li}, \mathrm{Ca}$, and K, the second cluster included $\mathrm{Al}, \mathrm{Zn}, \mathrm{Cu}, \mathrm{Mg}$, $\mathrm{Sr}$, and $\mathrm{Na}$, while the third cluster contained $\mathrm{Ba}, \mathrm{V}$, and almost all heavy metals ( $\mathrm{Cr}, \mathrm{Co}, \mathrm{Ni}, \mathrm{Cd}, \mathrm{Pb}, \mathrm{Mn}$, and $\mathrm{Fe}$ ). Li, $\mathrm{Ca}$, and $\mathrm{K}$ clustered closely together in the dendrogram, suggesting that those determinants are highly correlated.

\subsection{Plant Samples}

The highest Li content was measured in Lolium sp. collected from GWR28 and GWR27 (11.1 and $8.8 \mathrm{mg} / \mathrm{kg} \mathrm{DW)} \mathrm{(as} \mathrm{illustrated} \mathrm{in} \mathrm{Figure} \mathrm{4B).} \mathrm{The} \mathrm{Lolium} \mathrm{sp.} \mathrm{samples} \mathrm{from} \mathrm{GWR27}$ and GWR28 contained Li in 3- and 5-fold greater quantities than that of the Mentha sp. samples.

All the plant samples from GN and GWR6 had a low Li content $(\leq 0.2 \mathrm{mg} / \mathrm{kg} \mathrm{DW}$, with the exception of Lolium sp. from GWR6 at $0.45 \mathrm{mg} / \mathrm{kg}$ DW). In GWR29 and GWR30, Li content of plants was about $1 \mathrm{mg} / \mathrm{kg}$ DW. The Mentha sp. sample in GWR27 had the highest Fe and Al content, while the Lolium sp. had the highest Mn content compared to that of the other plant samples in this study (as illustrated in Figure 4A). High $\mathrm{Na}, \mathrm{Mg}$, and $\mathrm{K}$ contents were observed in Lolium sp. from GWR30 (as illustrated in Figure 4A). The plants with a lower Li content had higher $\mathrm{Ca}$ and $\mathrm{K}$ and lower $\mathrm{Mn}$ and Fe contents (i.e., Urtica sp. from GWR6 and GN). 

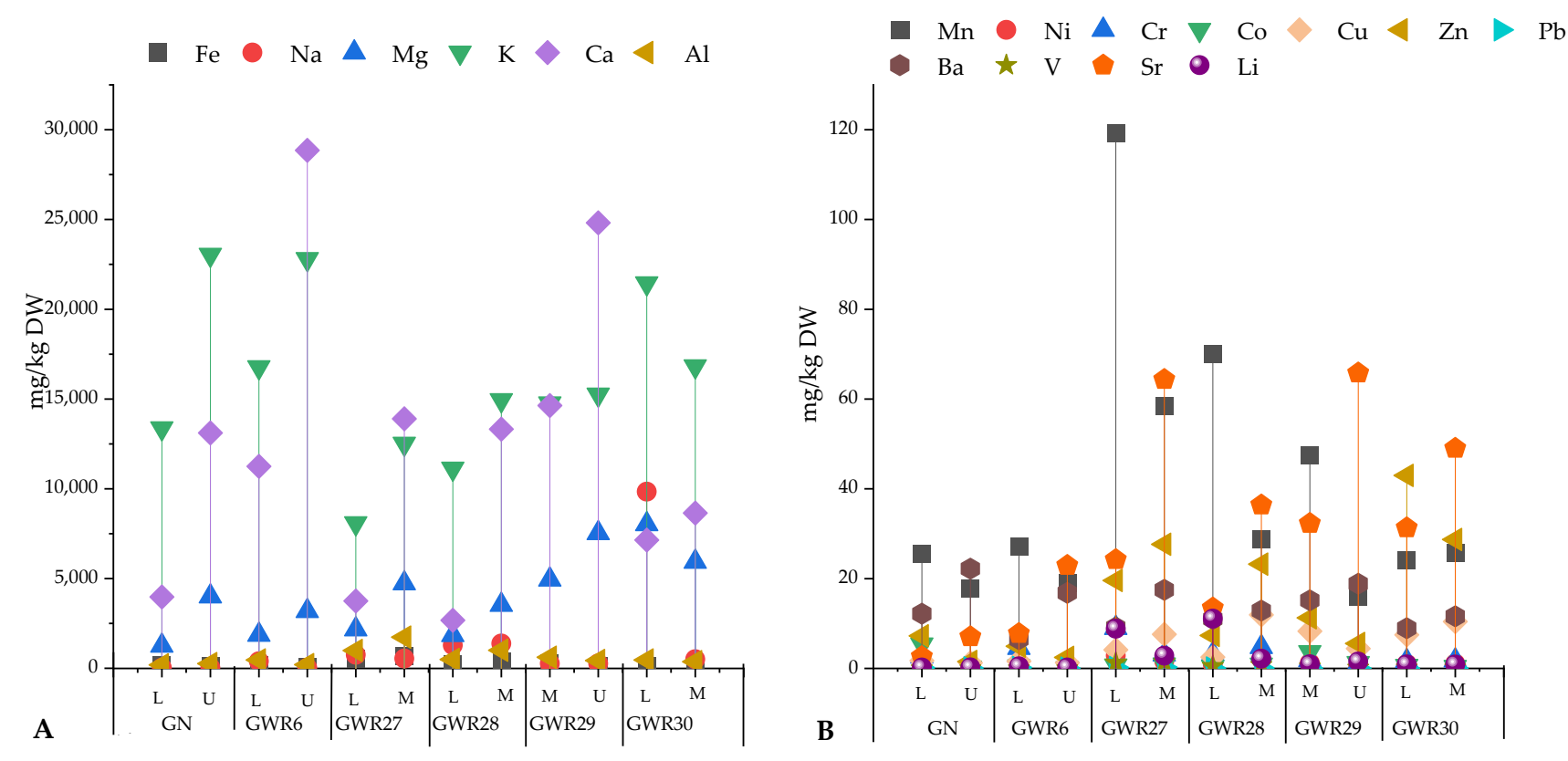

Figure 4. Macro (A) and microelement (B) content of plant samples (Lolium sp.-L, Urtica sp.-U, and Mentha sp.--M) in Banat (GN, GWR6) and Dobrogea (GWR27, GWR28, GWR29, and GWR30) region.

\subsection{Data Analysis}

The basic statistics (maximum, minimum, average, and standard deviation) for the microelements ( $\mathrm{Al}, \mathrm{Mn}, \mathrm{Ni}, \mathrm{Cr}, \mathrm{Co}, \mathrm{Cu}, \mathrm{Zn}, \mathrm{Pb}, \mathrm{V}, \mathrm{Sr}$, and $\mathrm{Li}$ ) in water, soil and plant samples in all the six-sampling locations are presented in Table 5.

The PCA results in case of the macro and microelements are presented in the Figure 5. The obtained results indicate that first three principal components (PCs) explain $70 \%$ of total variance. PC1 with the highest total variance accounted for $44.1 \%$ of the total variation and showed the highest loadings for $\mathrm{Fe}, \mathrm{Al}, \mathrm{Mn}$, and $\mathrm{Ni}$, with notable loadings from $\mathrm{Na}$, while $\mathrm{PC} 2$ revealed a $25.7 \%$ of the variability, with higher loadings for $\mathrm{Na}, \mathrm{Mg}, \mathrm{Ba}, \mathrm{Sr}, \mathrm{Cr}$ and with high contributions of K. Information about the correlations of macro- and microelements in water, soil, and plant samples are given through the position of the vectors. The PCA plot (as illustrated in Figure 5) shows the strong negative correlation between $\mathrm{Na}, \mathrm{Sr}, \mathrm{Mg}$, and $\mathrm{Li}$, stated by the position of the elements on opposite sides of the origin on the horizontal axis. A positive correlation between $\mathrm{Ba}$ and $\mathrm{Ca}$ or $\mathrm{Na}, \mathrm{Sr}$, and $\mathrm{Mg}$ can be seen by the same direction of the respective vectors; it can also be observed for $\mathrm{Li}, \mathrm{Ni}, \mathrm{Pb}, \mathrm{V}, \mathrm{Fe}, \mathrm{Al}, \mathrm{Mn}, \mathrm{Co}$, $\mathrm{Zn}$, and $\mathrm{K}$.

Therefore, the plants BCF was calculated to determine the accumulation of $\mathrm{Li}$ and other macro- and microelements in the sampled plants from Banat and Dobrogea regions. According to the obtained results, the Li uptake behavior show the plants adaptation to specific soil conditions. The plants nutrient uptake is influenced by the top soil metal concentrations. High Na BCF factor was observed in case of the Lolium sp. from the GWR30 sampling point (as illustrated in Figure 6), followed by the Lolium sp. from the GWR6 location. 
Table 5. Maximum (Max), minimum (Min), average (Avg), and standard deviation (SD) of microelement ( $\mathrm{Al}, \mathrm{Mn}, \mathrm{Ni}, \mathrm{Cr}, \mathrm{Co}, \mathrm{Cu}, \mathrm{Zn}, \mathrm{Pb}, \mathrm{V}, \mathrm{Sr}$, and $\mathrm{Li}$ ) concentration in water soil and plants.

\begin{tabular}{|c|c|c|c|c|c|c|c|c|c|c|c|c|}
\hline & Al & Mn & $\mathrm{Ni}$ & $\mathrm{Cr}$ & Co & $\mathrm{Cu}$ & Zn & $\mathrm{Pb}$ & Ba & V & Sr & $\mathbf{L i}$ \\
\hline \multicolumn{13}{|c|}{ Water $(\mu \mathrm{g} / \mathrm{L})$} \\
\hline Min & 0.14 & $<0.7$ & 2.15 & 2.27 & 0.23 & 0.98 & 2.50 & $<0.7$ & 15.2 & $<0.7$ & 180 & 1.40 \\
\hline Max & 0.70 & 0.45 & 5.00 & 52.4 & 0.45 & 2.56 & 17.0 & $<0.7$ & 60.3 & $<0.7$ & 613 & 12.2 \\
\hline Avg & 0.37 & 0.21 & 3.57 & 19.0 & 0.36 & 1.60 & 7.20 & $<0.7$ & 32.2 & $<0.7$ & 403 & 4.56 \\
\hline SD & 0.20 & 0.15 & 0.98 & 18.3 & 0.10 & 0.62 & 5.34 & $<0.7$ & 20.2 & $<0.7$ & 190 & 4.06 \\
\hline \multicolumn{13}{|c|}{ Soil (mg/kg DW) } \\
\hline Min & 6237 & 92.7 & 4.03 & 4.33 & 1.22 & 5.42 & 20.3 & 0.93 & 15.6 & 5.46 & 10.9 & 6.50 \\
\hline Max & 18760 & 261 & 13.5 & 19.1 & 6.14 & 13.7 & 50.4 & 6.54 & 58.2 & 24.8 & 94.7 & 11.3 \\
\hline Avg & 14638 & 179 & 8.02 & 11.2 & 3.00 & 10.3 & 32.7 & 2.95 & 39.4 & 12.4 & 59.3 & 9.45 \\
\hline SD & 4440 & 58.6 & 3.42 & 5.06 & 1.84 & 3.19 & 10.8 & 2.22 & 14.5 & 6.58 & 31.1 & 1.60 \\
\hline \multicolumn{13}{|c|}{ Plant-Lolium sp. (mg/kg DW) } \\
\hline Min & 187 & 24.2 & 0.73 & 1.65 & 0.3 & 1.59 & 4.93 & 0.06 & 6.50 & $<0.02$ & 2.63 & 0.02 \\
\hline Max & 991 & 119 & 2.85 & 9.01 & 5.3 & 7.48 & 43 & 0.21 & 12.2 & 1.26 & 31.3 & 11.1 \\
\hline Avg & 521 & 53.3 & 1.26 & 4.21 & 1.5 & 3.49 & 16.4 & 0.14 & 9.56 & 0.39 & 15.9 & 4.30 \\
\hline SD & 291 & 41.6 & 0.90 & 2.88 & 2.2 & 2.45 & 15.9 & 0.07 & 2.18 & 0.53 & 11.8 & 5.24 \\
\hline \multicolumn{13}{|c|}{ Plant-Urtica sp. (mg/kg DW) } \\
\hline Min & 203 & 15.9 & 0.37 & 0.30 & 0.10 & 1.24 & 1.54 & 0.05 & 16.9 & $<0.02$ & 7.0 & 0.19 \\
\hline Max & 439 & 19.1 & 0.50 & 0.91 & 1.20 & 4.43 & 5.55 & 0.13 & 22.2 & 0.14 & 65.8 & 1.54 \\
\hline Avg & 301 & 17.6 & 0.46 & 0.52 & 0.50 & 2.31 & 3.18 & 0.08 & 19.3 & 0.05 & 31.9 & 0.66 \\
\hline SD & 123 & 1.60 & 0.07 & 0.34 & 0.61 & 1.83 & 2.10 & 0.04 & 2.7 & 0.08 & 30.4 & 0.77 \\
\hline \multicolumn{13}{|c|}{ Plant-Mentha sp. (mg/kg DW) } \\
\hline Min & 372 & 25.7 & 1.09 & 1.75 & 0.36 & 7.59 & 11.3 & 0.07 & 11.6 & 0.18 & 32.3 & 0.88 \\
\hline Max & 1734 & 58.5 & 2.03 & 4.78 & 3.65 & 11.9 & 28.7 & 0.26 & 17.5 & 1.35 & 64.4 & 2.84 \\
\hline Avg & 933 & 40.1 & 1.48 & 2.86 & 1.44 & 9.56 & 22.7 & 0.13 & 14.3 & 0.66 & 45.5 & 1.70 \\
\hline SD & 595 & 15.6 & 0.42 & 1.42 & 1.49 & 1.99 & 7.99 & 0.08 & 2.59 & 0.51 & 14.4 & 0.96 \\
\hline
\end{tabular}

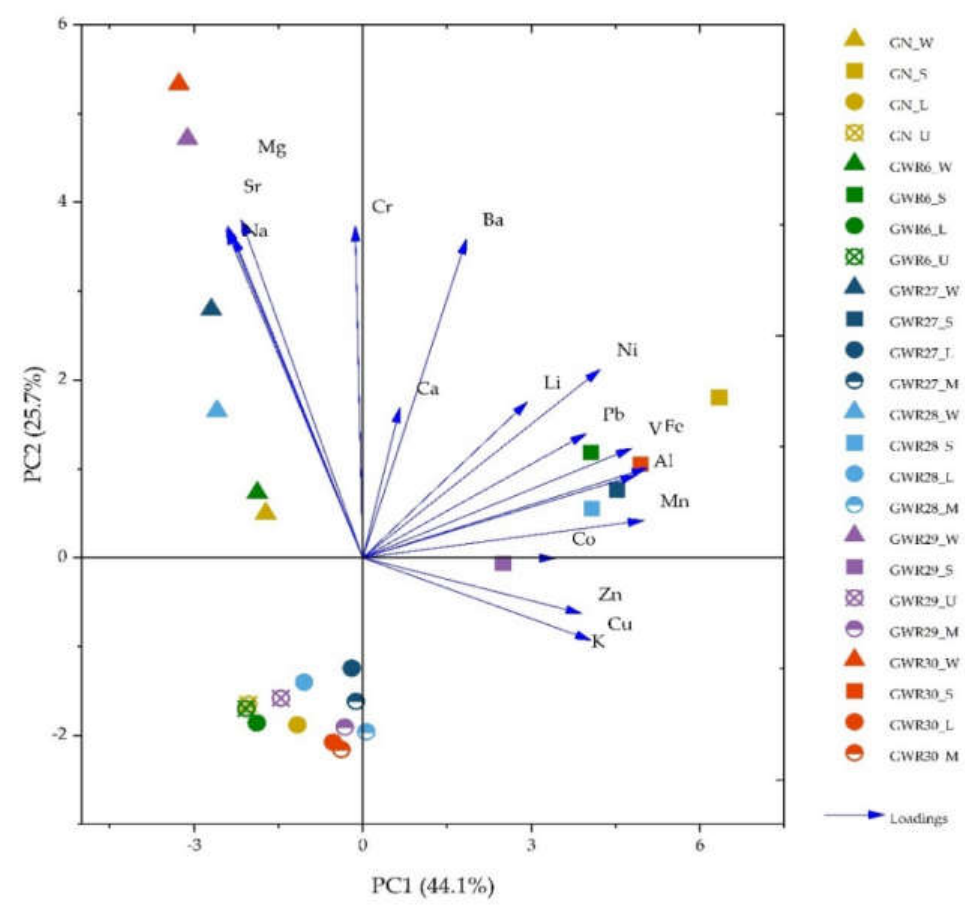

Figure 5. Principal component analysis (PCA) of variation of macro- and microelements in water, soil, and plant samples (L-Lolium sp., U-Urtica sp., and M-Mentha sp.) in Banat (GN, GWR6) and Dobrogea region (GWR27, GWR28, GWR29, and GWR30). 


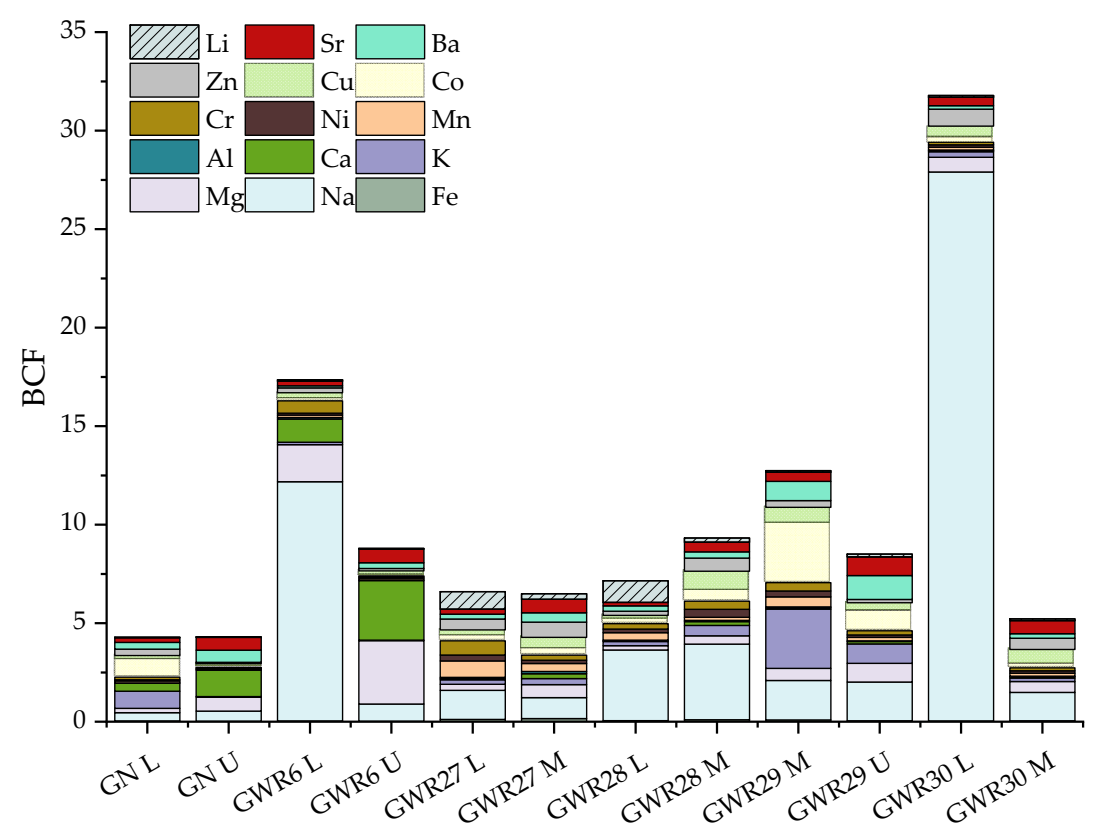

Figure 6. Bioconcentration factor (BCF) of macro- and microelements in plant species (Lolium sp.-L, Urtica sp.-U, and Mentha sp.-M) in Banat (GN, GWR6) and Dobrogea (GWR27, GWR28, GWR29, and GWR30) region.

\section{Discussion}

Li concentration in the studied water samples differed among aquifer lithotypes because of the difference in $\mathrm{Li}$ abundance among rock types. Moreover, Lindsey et al. stated that aridity and aquifer age and its proximity to geothermal features are also definitory factors in controlling the evaluation of Li concentrations in water [4]. The highest concentration of Li in water was identified in GWR27 and GWR28, the sampling sites characterized by sandstone, while the lowest Li concentration was in GN and GWR6, characterized by areas with a limestone-confined aquifer. Similar results were reported in the United State, where carbonate rocks had low Li content, while unconsolidated sandstone and crystalline-rock aquifer had high Li content [4].

The chemical composition of water is also highly influenced by hydrology, water-rock interactions, and chemical weathering fluxes. $\mathrm{Li}$ is part of the alkali metal groups such as $\mathrm{Na}$, which can act similarly during weathering processes according to Steinkoenig et al. [23]. The soil Li content is mainly controlled by weathering processes or atmospheric inputs and can be also correlated to water Li concentration. Generally, previous study showed that the Li content in soils was also correlated with $\mathrm{Ca}$ and $\mathrm{K}$ contents, which are derived from weathering of parental bedrock of transported alluvial or glacier materials [24]. Thus, the slightly higher Li content from waters and soils sampled from Dobrogea region could be due to the closeness with the Black Sea. Martin et al. estimated that, in the case of fresh water from Rottnest Island, atmospheric input via rainfall and sea-spray aerosols was the second most important source of Li, followed by carbonate dissolution [12,25].

The trace metal concentrations were in the admissible range for the Banat and Dobrogea regions according to the limit values established in Romanian legislation for water bodies and alert thresholds for sensitive soil uses [26,27].

The correlation of $\mathrm{Li}, \mathrm{Ca}$, and $\mathrm{K}$ content in soil samples was reported also by other studies; $\mathrm{K}$ and $\mathrm{Li}$ could have a common source as a result of rock-water interaction and water-soil transfer mechanisms $[24,28]$. Li, $\mathrm{Ca}$, and $\mathrm{K}$ were decoupled from the heavy metals ( $\mathrm{Fe}, \mathrm{Mn}, \mathrm{Pb}, \mathrm{Cd}, \mathrm{Ni}, \mathrm{Co}$, and $\mathrm{Cr}$ ) in the $\mathrm{HCA}$ suggesting that the firsts behave quite differently and independent to each other (as illustrated in Figure 3).

Plant species have different metabolisms and the elements accumulation capacity is highly influenced by the growth medium. The Li bioavailability, uptake, and accumulation 
could be influenced by several factors related to soil ( $\mathrm{pH}$, moisture, metal content, etc.) [29]. Various metals at higher concentrations can cause serious health disorder in plants due to their nonbiodegradability, high bioaccumulation rate, and biotoxicity effects [30]. However, plants can develop and can adapt to extreme environmental conditions, due to their unique uptake mechanism, soil-root-shoot nutrient transfer mechanisms, and metal interaction with the available metal mixtures from the growing area [30]. Nonessential elements such as $\mathrm{Cd}$ and $\mathrm{Pb}$ can produce synergistic or antagonistic effects on the uptake and accumulation of $\mathrm{K}, \mathrm{Ca}, \mathrm{Mg}$, $\mathrm{Fe}$, and $\mathrm{Mn}$ [30].

In the present study, for the plants with high Na content, BCF ratio indicates high salinity tolerance ability. Generally, $\mathrm{Li}$ is considered a nonessential element for plant growth and development, and for halophyte species (plants that tolerate moderate to high salt concentrations in their substrate), Li plays an important role in their metabolism. Moreover, Li was reported previously by several studies to enhance plant productivity, yield, early maturation, and resistance to diseases [31,32]. A Li accumulation in soil is the result of ions release from rocks to clay and soil, where it can be fixed into organic matter or mineral oxides [29]. The plants $\mathrm{Li}$ level is directly correlated with the uptake of $\mathrm{Fe}, \mathrm{Ni}, \mathrm{Co}, \mathrm{Mn}, \mathrm{Cu}$, $\mathrm{Al}, \mathrm{Pb}$, or $\mathrm{Cd}$ from the soil [33]. High Li uptake can occur in soils with equally high $\mathrm{Na}$ content such as soil with a natric horizon (also known as solonetz soils). In the present study, the obtained results indicated that plants $\mathrm{Li}$ uptake could be enhanced by $\mathrm{Na}$, soil samples with the highest Na content were measured in GWR27 and GWR28, where also the highest $\mathrm{Li}$ BCF values were found in the Lolium sp. plants. However, despite the high $\mathrm{Na}$ and Li presence in GWR30 soil samples, a low Li BCF was observed in Lolium sp. This can be attributed to the plant's adaptation mechanism and the specific environmental/soil conditions that include the presence of other elements such are $\mathrm{Mg}, \mathrm{K}$, and $\mathrm{Ca}$. These three elements can produce antagonistic effects on $\mathrm{Li}$ and synergetic effects on the uptake of $\mathrm{Na}$. For GWR29 and GWR30 soils the high Ca content (2-4-fold greater than in GWR27 and GWR28) inhibits and competes with the Li uptake. Studies based on the Li soil-atmospherebiosphere exchange showed that $\mathrm{Li}$ content had specific effects on the uptake of other essential or trace elements [34]. The plant Li content was negatively correlated with $\mathrm{Mg}$, $\mathrm{Mn}$, and Mo, while a positive correlation was noticed with $\mathrm{Ca}, \mathrm{Fe}, \mathrm{K}$, and $\mathrm{Zn}$, indicating that $\mathrm{Li}$ changes the function of the essential element transporters [34]. The Li ion can have an adverse effect on the plant growth and interferes with the Ca metabolism [35]. In the present study the lowest BCF of Li was obtained in plants sampled in GN and GWR6 sites, while the highest $\mathrm{K}$ and $\mathrm{Ca} \mathrm{BCF}$ ratio were obtained in Urtica sp. and Lolium sp. from GWR6, followed by the Urtica sp. from GN site. These results indicate that a competitive interaction with Li may occur during the adsorption of essential elements, such as $\mathrm{Ca}$ and $\mathrm{K}$. The low BCF values of Li was accompanied by high Ba and Sr ratio in Urtica sp. and Mentha sp. from GWR29 sampling site, which indicates that soils higher K and Ca content may regulate and enhance the Ba and $\mathrm{Sr}$ uptake in the plants. However, further studies need to be done to fully understand the importance and/or inadequate role of $\mathrm{Li}$ and its competition with other trace elements during the nutrient uptake in the rhizosphere zone.

\section{Conclusions}

In this study, a versatile measurement method was optimized for the determination of Li from multiple matrixes (water, soil, and plant) using ICP-MS technique. The obtained results indicated an acceptable precision in all studied matrixes and a reproducibility of $2.46-4.22 \%$. Higher Li concentrations were obtained both for water and soil in Dobrogea region compared to Banat region. Despite the high Li concentrations in soils, it was mostly unavailable for the plant's uptake and bioaccumulation, as shown by the low bioconcentration values. The highest Li content was accumulated in Lolium sp. plants from two sites from the Dobrogea region, most probably due to the Li bioavailability, influenced by the soil characteristics and other trace element content such as alkali and alkali-earth elements $(\mathrm{K}, \mathrm{Na}, \mathrm{Mg}, \mathrm{Ca}, \mathrm{Ba})$. The obtained results revealed that the Li content in soil was correlated with $\mathrm{Ca}$ and $\mathrm{K}$, suggesting a strong association between their chemical 
behavior. The Li uptake and translocation in plants could be attributed to the monovalent cation in the presence of potential ligands in soil helping Li mobility and accumulation in the rhizosphere. The prolonged high Li concentrations effect is still unknown and further studies are needed to understand the Li transfer from soil to plants, identification of plants species which can accumulate Li from contaminated areas, and the main Li uptake/ translocation mechanism in different plant species.

Supplementary Materials: The following are available online at https:/ /www.mdpi.com/article/10

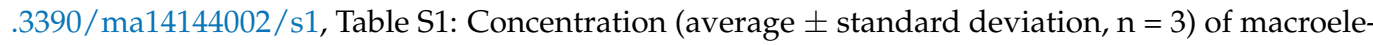
ments in water, soil and plant samples ( $\mathrm{L}=$ Lolium sp., $\mathrm{U}=$ Urtica sp., $\mathrm{M}=$ Mentha sp.). Table S2: Concentration (average \pm standard deviation, $\mathrm{n}=3$ ) of microelements in water, soil and plant samples (Lolium sp., $\mathrm{U}=$ Urtica sp., $\mathrm{M}=$ Mentha sp.).

Author Contributions: Conceptualization, A.I.T., E.A.L. and O.C.; methodology, A.I.T., A.M. and C.T.; analysis, A.I.T., A.M. and C.T.; writing—original draft preparation, A.I.T., A.M. and C.T.; writing-review and editing, O.C., E.A.L. and O.T.M.; funding acquisition, O.T.M. All authors read and agreed to the published version of the manuscript.

Funding: Sampling and laboratory analysis were supported by a grant of the Ministry of Research, Innovation and Digitization, CNCS/CCCDI-UEFISCDI, project number 2/2019 (DARKFOOD), within PNCDI III, and results interpretation were supported by the EEA grants 2014-2021, under project GROUNDWATERISK, contract no. 4/2019. The APC was funded by the Ministry of Research, Innovation and Digitization, CNCS/CCCDI-UEFISCDI, project number 2/2019 (DARKFOOD), within PNCDI III.

Institutional Review Board Statement: Not applicable.

Informed Consent Statement: Not applicable.

Data Availability Statement: The data presented in this study are available on request from the corresponding author.

Conflicts of Interest: The authors declare no conflict of interest.

\section{References}

1. Bibienne, T.; Magnan, J.-F.; Rupp, A.; Laroche, N. From Mine to Mind and Mobiles: Society's Increasing Dependence on Lithium. Elements 2020, 16, 265-270. [CrossRef]

2. Barjasteh-Askari, F.; Davoudi, M.; Amini, H.; Ghorbani, M.; Yaseri, M.; Yunesian, M.; Mahvi, A.H.; Lester, D. Relationship between suicide mortality and lithium in drinking water: A systematic review and meta-analysis. J. Affect Disord. 2020, 264, 234-241. [CrossRef]

3. Turekian, K.K.; Wedepohl, K.H. Distribution of the Elements in Some Major Units of the Earth's Crust. GSA Bull. 1961, 72, 175-192. [CrossRef]

4. Lindsey, B.D.; Belitz, K.; Cravotta, C.A.; Toccalino, P.L.; Dubrovsky, N.M. Lithium in groundwater used for drinking-water supply in the United States. Sci. Total Environ. 2021, 767, 144691. [CrossRef]

5. Szklarska, D.; Rzymski, P. Is Lithium a Micronutrient? From Biological Activity and Epidemiological Observation to Food Fortification. Biol. Trace Elem. Res. 2019, 189, 18-27. [CrossRef]

6. Knudsen, N.N.; Schullehner, J.; Hansen, B.; Jorgensen, L.F.; Kristiansen, S.M.; Voutchkova, D.D.; Gerds, T.A.; Andersen, P.K.; Bihrmann, K.; Gronbaek, M.; et al. Lithium in Drinking Water and Incidence of Suicide: A Nationwide Individual-Level Cohort Study with 22 Years of Follow-Up. Int. J. Environ. Res. Public Health 2017, 14, 627. [CrossRef] [PubMed]

7. Ng, J.; Sjöstrand, M.; Eyal, N. Adding Lithium to Drinking Water for Suicide Prevention—The Ethics. Public Health Ethics 2019, 12, 274-286. [CrossRef]

8. Voica, C.; Roba, C.; Iordache, A.M. Lithium Levels in Food from the Romanian Market by Inductively Coupled Plasma-Mass Spectrometry (ICP-MS): A Pilot Study. Anal. Lett. 2021, 54, 242-254. [CrossRef]

9. Bernard, A. Chapter 44-Lithium. In Handbook on the Toxicology of Metals, 4th ed.; Nordberg, G.F., Fowler, B.A., Nordberg, M., Eds.; Academic Press: San Diego, CA, USA, 2015; pp. 969-974. [CrossRef]

10. Bäuchle, M.; Lüdecke, T.; Rabieh, S.; Calnek, K.; Bromage, T.G. Quantification of 71 detected elements from Li to U for aqueous samples by simultaneous-inductively coupled plasma-mass spectrometry. RSC Adv. 2018, 8, 37008-37020. [CrossRef]

11. Zektser, I.S.; Everett, L.G. Groundwater Resources of the World and Their Use; UNESCO: Paris, France, 2004.

12. Martin, A.N.; Meredith, K.; Norman, M.D.; Bryan, E.; Baker, A. Lithium and strontium isotope dynamics in a carbonate island aquifer, Rottnest Island, Western Australia. Sci. Total Environ. 2020, 715, 136906. [CrossRef] 
13. Sugawara, N.; Yasui-Furukori, N.; Ishii, N.; Iwata, N.; Terao, T. Lithium in tap water and suicide mortality in Japan. Int. J. Environ. Res. Public Health 2013, 10, 6044-6048. [CrossRef]

14. Bluml, V.; Regier, M.D.; Hlavin, G.; Rockett, I.R.; Konig, F.; Vyssoki, B.; Bschor, T.; Kapusta, N.D. Lithium in the public water supply and suicide mortality in Texas. J. Psychiatr. Res. 2013, 47, 407-411. [CrossRef]

15. Dai, L.; Wigman, L.; Zhang, K. Sensitive and direct determination of lithium by mixed-mode chromatography and charged aerosol detection. J. Chromatogr. A 2015, 1408, 87-92. [CrossRef] [PubMed]

16. Moldovan, A.; Hoaghia, M.-A.; Kovacs, E.; Mirea, I.C.; Kenesz, M.; Arghir, R.A.; Petculescu, A.; Levei, E.A.; Moldovan, O.T. Quality and Health Risk Assessment Associated with Water Consumption-A Case Study on Karstic Springs. Water 2020, 12, 3510. [CrossRef]

17. Belic, M.; Nesic, L.; Ciric, V.; Vasin, J.; Milosev, D.; Seremesic, S. Characteristics and classification of gleyic soils of Banat. Ratar. Povrt. 2011, 48, 375-382. [CrossRef]

18. Florea, B.P. Soil Map-Generalised from 1:1000,000 soil Map of the Atlas of Romania. In Atlasul R.S.Romania; National Soil Maps (EUDASM): Bucharest, Romania, 1978.

19. Miclean, M.; Cadar, O.; Levei, L.; Senila, L.; Ozunu, A. Metal contents and potential health risk assessment of crops grown in a former mining district (Romania). J. Environ. Sci. Health B 2018, 53, 595-601. [CrossRef]

20. Senila, M.; Drolc, A.; Pintar, A.; Senila, L.; Levei, E. Validation and measurement uncertainty evaluation of the ICP-OES method for the multi-elemental determination of essential and nonessential elements from medicinal plants and their aqueous extracts. $J$. Anal. Sci. Technol. 2014, 5, 37. [CrossRef]

21. Wu, J.; Li, P.; Qian, H.; Duan, Z.; Zhang, X. Using correlation and multivariate statistical analysis to identify hydrogeochemical processes affecting the major ion chemistry of waters: A case study in Laoheba phosphorite mine in Sichuan, China. Arab. J. Geosci. 2014, 7, 3973-3982. [CrossRef]

22. Gajić, G.; Mitrović, M.; Pavlović, P. 6-Feasibility of Festuca rubra L. native grass in phytoremediation. In Phytoremediation Potential of Perennial Grasses; Pandey, V.C., Singh, D.P., Eds.; Elsevier: Amsterdam, The Netherlands, 2020; pp. 115-164. [CrossRef]

23. Steinkoenig, L.A. Lithium in Soils. J. Ind. Eng. Chem. 2002, 7, 425-426. [CrossRef]

24. Smith, D.B.; Cannon, W.F.; Woodruff, L.G.; Solano, F.; Ellefsen, K.J. Geochemical and Mineralogical Maps for Soils of the Conterminous United States; U.S. Geological Survey: Reston, VA, USA, 2014; p. 399.

25. Souid, F.; Agoubi, B.; Telahigue, F.; Chahlaoui, A.; Kharroubi, A. Groundwater salinization and seawater intrusion tracing based on Lithium concentration in the shallow aquifer of Jerba Island, southeastern Tunisia. J. Afr. Earth Sci. 2018, 138, 233-246. [CrossRef]

26. Ministerial Order, No. 621/2014 on the Approval of Threshold Values for Groundwater in Romania. Available online: http: / / legislatie.just.ro/Public/DetaliiDocumentAfis/159990 (accessed on 23 February 2021).

27. Ministerial Order, No. 756/1997 for the Approval of the Procedure for Carrying out the Environmental Assessments. Available online: https:/ / stratos.ro/wp-content/uploads/2020/03/ordinul-nr-756-1997.pdf (accessed on 23 February 2021).

28. Souid, F.; Agoubi, B.; Hamdi, M.; Telahigue, F.; Kharroubi, A. Groundwater chemical and fecal contamination assessment of the Jerba unconfined aquifer, southeast of Tunisia. Arab. J. Geosci. 2017, 10, 231. [CrossRef]

29. Hayyat, M.U.; Nawaz, R.; Siddiq, Z.; Shakoor, M.B.; Mushtaq, M.; Ahmad, S.R.; Ali, S.; Hussain, A.; Irshad, M.A.; Alsahli, A.A.; et al. Investigation of Lithium Application and Effect of Organic Matter on Soil Health. Sustainability 2021, 13, 1705. [CrossRef]

30. Khan, A.; Khan, S.; Alam, M.; Khan, M.A.; Aamir, M.; Qamar, Z.; Rehman, Z.U.; Perveen, S. Toxic metal interactions affect the bioaccumulation and dietary intake of macro- and micro-nutrients. Chemosphere 2016, 146, 121-128. [CrossRef]

31. Shahzad, B.; Tanveer, M.; Hassan, W.; Shah, A.N.; Anjum, S.A.; Cheema, S.A.; Ali, I. Lithium toxicity in plants: Reasons, mechanisms and remediation possibilities-A review. Plant Physiol. Biochem. 2016, 107, 104-115. [CrossRef] [PubMed]

32. Anderson, C.E. Lithium in Plants. In Lithium and Cell Physiology; Bach, R.O., Gallicchio, V.S., Eds.; Springer: New York, NY, USA, 1990.

33. Schrauzer, G.N. Lithium: Occurrence, dietary intakes, nutritional essentiality. J. Am. Coll. Nutr. 2002, 21, 14-21. [CrossRef] [PubMed]

34. Robinson, B.H.; Yalamanchali, R.; Reiser, R.; Dickinson, N.M. Lithium as an emerging environmental contaminant: Mobility in the soil-plant system. Chemosphere 2018, 197, 1-6. [CrossRef]

35. Allender, W.J.; Cresswell, G.C.; Kaldor, J.; Kennedy, I.R. Effect of lithium and lanthanum on herbicide induced hormesis in hydroponically-grown cotton and corn. J. Plant Nutr. 1997, 20, 81-95. [CrossRef] 